\title{
The Economics of
}

Hydroponic Greenhouse Production for Cucumbers and Tomatoes

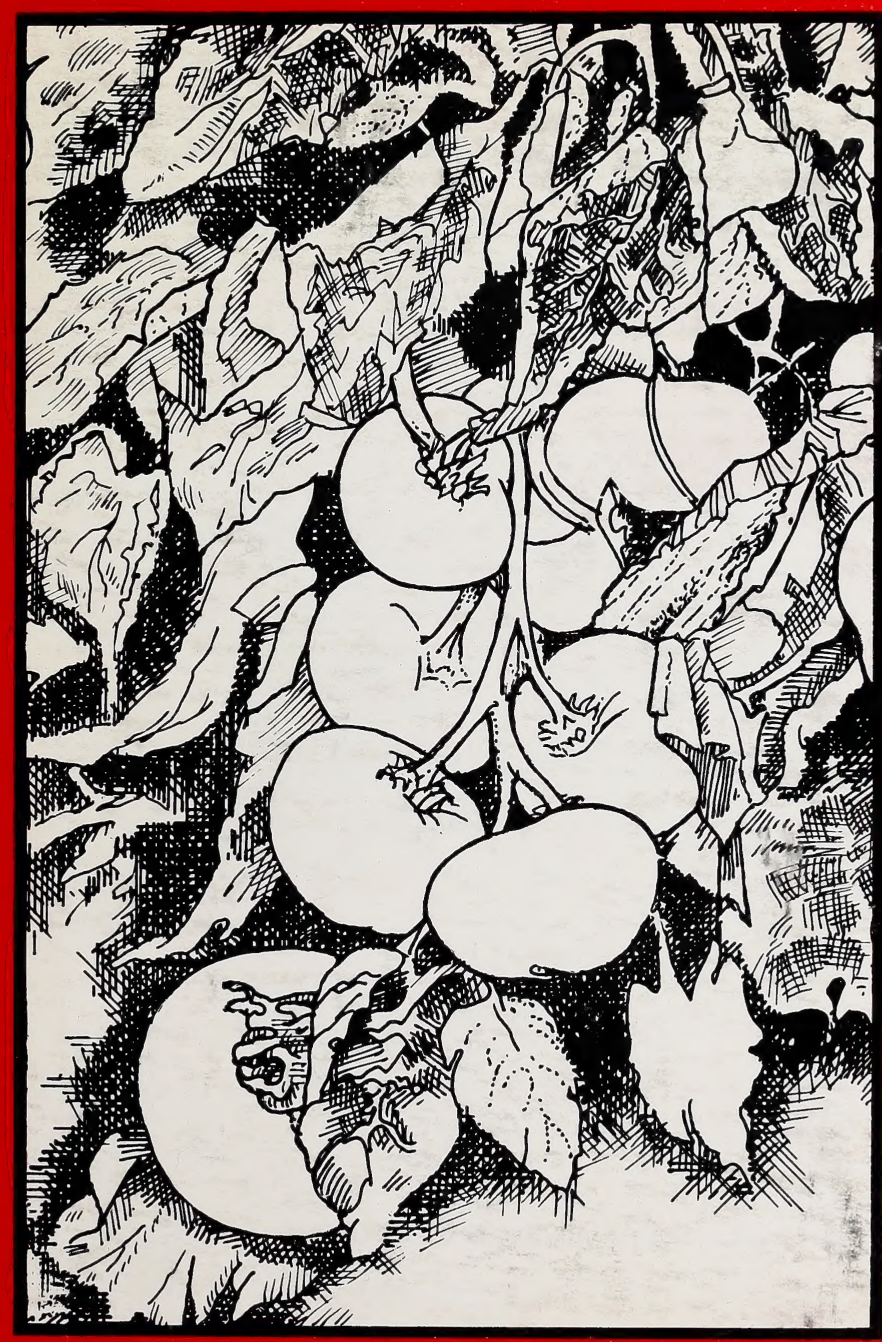

\section{Aborta}

AGRICULTURE

Production and Resource

Economics Branch

AGDEX 821-50 

National Library Bibliotheque nationale
of Canada
du Canada 
THE ECONOMICS OF HYDROPONIC GREENHOUSE PRODUCTION FOR

CUCUMBERS AND TOMATOES

BY

G. NABI CHAUDHARY

PRODUCTION \& RESOURCE ECONOMICS BRANCH ALBERTA AGRICULTURE

NOVEMBER, 1987 
880314 


\section{ACKNOWLEDGEMENTS}

The author wishes to express sincere thanks to all the hydroponic greenhouse operators in Alberta who willingly provided valuable data for this study. The assistance provided by Reynold Jaipaul in computer programming and analysis of the data is gratefully acknowledged. 


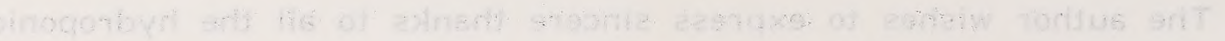

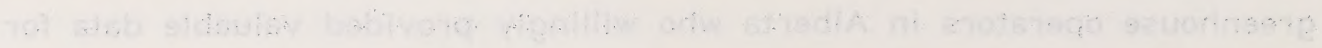

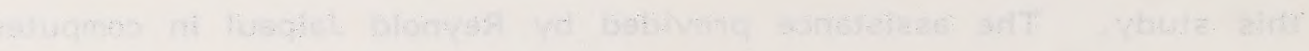

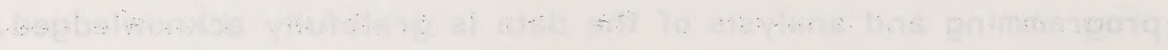


Although Alberta greenhouse vegetables and flowers are customarily grown in a soil medium, every year Alberta Agriculture receives inquiries about the economic feasibility of hydroponic (or soilless) greenhouse crop production. While natural soil fertility, technical know-how and relative costs favour the use of soil, hydroponic greenhouses are capable of sustaining the same level of production as conventional greenhouses. Commercial growers as well as hobbyists want to know the advantages, disadvantages, and the underlying costs of the two systems.

This study presents a profile of hydroponic greenhouse production costs and returns for tomatoes and cucumbers grown in Alberta. The sample size is small. Nevertheless, the report does give a reasonable indication of the economics of hydroponics. Management is a key factor and the report serves as a starting point for discussion and further research into the economic feasibility of hydroponic farming in Alberta. Growers are invited to review this report and to contact $\mathrm{Mr}$. Chaudhary if they have any questions or comments. Mr. Chaudhary can be reached by telephone at 427-5395.

Carlyle Ross

Branch Head

Production \& Resource

Economics Branch 
Digitized by the Internet Archive in 2015 
ACKNOWLEDGEMENTS ................ FOREWORD ..................... ii

LIST OF TABLES ................ . . $v$

LIST OF FIGURES ............. . . . vi

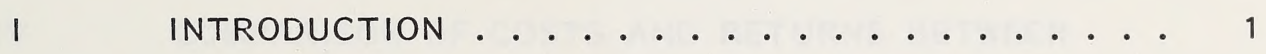

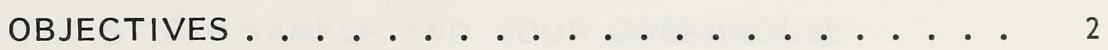

THE STUDY SAMPLE ................ 2

CAUTIONARY NOTE ................ 2

II HYDROPONIC GREENHOUSE OPERATIONS IN ALBERTA. 3

Hydroponic: A Brief Description ....... 3

Hydroponic Greenhouse Area by Type of

Structure ............. . . 6

III HYDROPONIC GREENHOUSE PRODUCTION COSTS

AND RETURNS ....................... 9

Computation of Individual Cost Components . . . 9

Hydroponic Greenhouse Investment Costs . . . 11

Hydroponic Greenhouse Operating Costs . . . . 15

Hydroponic Greenhouse Production Costs

and Returns ........... . . 15

Investment Costs for Hydroponic Greenhouses

Producing Cucumbers ......... 16

Operating Costs for Hydroponic Greenhouses

Producing Cucumbers . . . . . . . . 16

Production Costs and Returns for Hydroponic

Greenhouses Producing Cucumbers . . . . . 18

Investment Costs for Hydroponic Greenhouses

Producing Tomatoes .......... 18 


\section{TABLE OF CONTENTS - Cont'd}

SECTION

PAGE

Operating Costs for Hydroponic Greenhouses

Producing Tomatoes . . . . . . . . 18

Production Costs and Returns for Hydroponic

Greenhouses Producing Tomatoes . . . . . . 21

IV COMPARISON OF COSTS AND RETURNS BETWEEN

THE STUDY SAMPLE AND YOUR GREENHOUSE

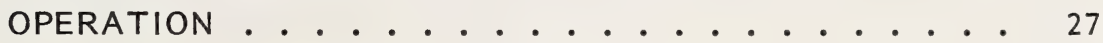

$\mathrm{V}$

SUMMARY

Distribution of Hydroponic Greenhouse

Production Costs ........... 31

Production and Marketing Problems for

Hydroponic Greenhouses.......... 34 

Average Hydroponic Greenhouse Investment and Investment Costs in Alberta ...........

Average Hydroponic Greenhouse Operating Costs in Alberta . . . . . . . . . . . . .

Average Hydroponic Greenhouse Production Costs and Returns in Alberta. . . . . . . . . . .

Average Hydroponic Greenhouse Investment and Investment Costs for Cucumbers . . . . . . . . .

Average Hydroponic Greenhouse Operating Costs for Cucumbers.

Average Hydroponic Greenhouse Production Costs and Returns for Cucumbers. . . . . . . . . . .

Average Hydroponic Greenhouse Investment and Investment Costs for Tomatoes . . . . . . . . . .

Average Hydroponic Greenhouse Operating Costs for Tomatoes

Average Hydroponic Greenhouse Production Costs and Returns for Tomatoes ............. Greenhouse Operation . . . . . . . . . . 



\section{LIST OF FIGURES}

FIGURE

Typical Container for Single Plant Solution Culture Aquarium Pump Supplies Operation . . . . . . . . 5

Aeration for Multiple-Plant Solution Culture Trough Provided by an Outside Source. . . . . . . . . .

3 Nutrient Film or Flow Culture Using Plastic Film to Hold and Feed Plants Through a Recirculation System . . . . 5

Distribution of Hydroponic Greenhouse Production Costs for Cucumbers .................

Distribution of Hydroponic Greenhouse Production Costs for Tomatoes . . . . . . . . . . . . . . 



\section{INTRODUCTION}

The hydroponic technique for the production of greenhouse crops was introduced in Alberta in the early eighties. ${ }^{1}$ Tomatoes were the first crop grown commercially in the hydroponic greenhouses. Other greenhouse crops grown by the hydroponic technique are lettuce and long English cucumbers.

Because of the increased demand for information on hydroponic greenhouse production costs and returns, a study was undertaken to document such costs. Although the sample size was relatively small, the information obtained from the study participants is considered adequate for guideline purposes.

This brief report provides the most current information on hydroponic greenhouse production costs and returns for the two major crops (tomatoes and cucumbers) produced in 1986. Only one hydroponic greenhouse operator was able to provide some information on lettuce production, which could not be used due to the confidentiality of the data.

1 "HYDROPONICS" is a crop production technique which uses a controlled environment to replace soil with a sterile growing medium and automatic watering and feeding system generally. It leads to faster growth, higher yields, less work, more precise control of watering and feeding, fewer diseases, a cleaner operation and better quality produce. On the negative side, initial installation costs are higher and a greater degree of technical skill is required to maximize results. 
The major objectives of the study are:

1. To estimate hydroponic greenhouse production costs and returns by major crops.

2. To identify the factors influencing production and marketing of hydroponic greenhouse crops.

3. To identify problems experienced by hydroponic greenhouse operators in Alberta.

\section{THE STUDY SAMPLE}

Almost all of the hydroponic greenhouse operators (11) in the province were contacted to participate in the study. The three largest greenhouse operators declined to provide any information on their operations. Two hydroponic greenhouses were just starting production of crops and did not have enough data. One lettuce producing hydroponic greenhouse operator provided records which could not be used in the analysis due to the confidentiality of the data. Of the remaining five hydroponic greenhouse operators, only four were able to provide complete records of their business, and one was not contacted. Therefore, the results presented in this study are based on four study participants.

\section{CAUTIONARY NOTE}

The users of this information are advised to use caution when interpreting the results contained in the report. Hydroponic production techniques are only economically feasible if good management skills and marketing expertise are applied. In some instances, production and marketing problems became apparent during the course of the study, and are reflected in return to management. 


\section{HYDROPONIC GREENHOUSE OPERATIONS IN ALBERTA}

\section{Hydroponic: A Brief Description ${ }^{2}$}

Hydroponic is a plant-feeding method in which all constituents of normal soil-root environment are absent except water, inorganic salts, and air. There are certain advantages to hydroponic culture. It avoids problems such as poor soil structure, poor drainage and nonuniform texture, weeds and (with proper sanitation practices) pathologic soil organisms which are often encountered in conventional culture. The automated controls used in hydroponic culture reduce some of the management decisions on amounts and timing of fertilization and irrigation, but at the same time force the grower to face others. For instance, the hydroponic grower must substitute for "Mother Nature" and keep in balance all of the chemical, physical and biological systems which aid plant growth. Hydroponic provides less buffering action to maintain the needed $\mathrm{pH}$, or acidity-alkalinity ratio. It is up to the grower to do this and to also control the availability of plant nutrients. No clay particles or organic matter are present to store and gradually release plant nutrients, and accumulation of toxic elements in the solution must be avoided. Because the water holding capacity of gravel or sand systems is exceedingly small compared to soil, power is required to pump water to the plants. Malfunctions in the system will result in rapid wilting and potentially serious plant stress effects. Also, hydroponic systems lack soil's wide range of micro-organisms that can act as

2 For details on different 'Hydiroponic' methods, see "HYDROPONICS"A GUIDE TO SOILLESS CULTURE SYSTEMS" BY Dr. Mirza Mohyuddin, Alberta Tree Nursery and Horticulture Centre, Edmonton, Alberta, January, 1987. 
antagonists and suppress soil-borne pathogens. While soil-less systems are generally free of diseases initially, they can be infected readily and serious plant losses can occur. But the most important disadvantage is that this method of plant growing is more costly than soil culture because of the specialized equipment required.

The term "hydroponic" was used first by W.F. Gericke in 1937 to describe a method of feeding plants whose roots were immersed in an aerated, dilute solution of fertilizer salts. The method was developed long before Gericke's time however, and is still widely used in all countries by plant scientists in plant nutrition studies. The term "solution culture" is commonly applied to this basic form of hydroponics to distinguish it from other modifications now used experimentally and commercially. The modified systems used pea gravel, sand, volcanic rock, and other relatively inert materials to provide support for the root system. These materials have enough water and nutrient holding capacity so that intermittent flooding or irrigation with the nutrient solution provides the necessary water, nutrients, and aeration to the root system.

There are other modifications which are generally referred to as "artificial soils" since they are prepared from materials that more closely approximate soil in nutrient and water holding capacity. Widely used commercially, they include various mixtures of sphagnum peat, vermiculite, perlite, and wood shavings, sand, or even wheat-straw bales.

Pure hydroponic or solution culture systems may be either static or flowing. Static systems require that air constantly be bubbled through the solution around the roots to supply them with oxygen. This can be done with an aquarium pump equipped with plastic tubing attached to air stones (Figures 1 and 2). Containers can be of glass, plastic, earthenware, or wood troughs lined with polyethylene film. In a flow culture system (Figure 3 ) the nutrient solution provides aeration as it flows through the troughs in which the plants are growing. The troughs are constructed with a slight slope to allow the solution to drain back to the sump tank from which it is repumped to the head of the trough. The depth of solution in the troughs is maintained, by flow rate and slope, so as to barely cover the root system. Troughs have 
been constructed of many materials: asphalt-lined wood or concrete, wood with plastic liners, fiberglass, and more recently, large-diameter PVC pipes or "lay-flat" polyethylene tubing. Detailed descriptions for
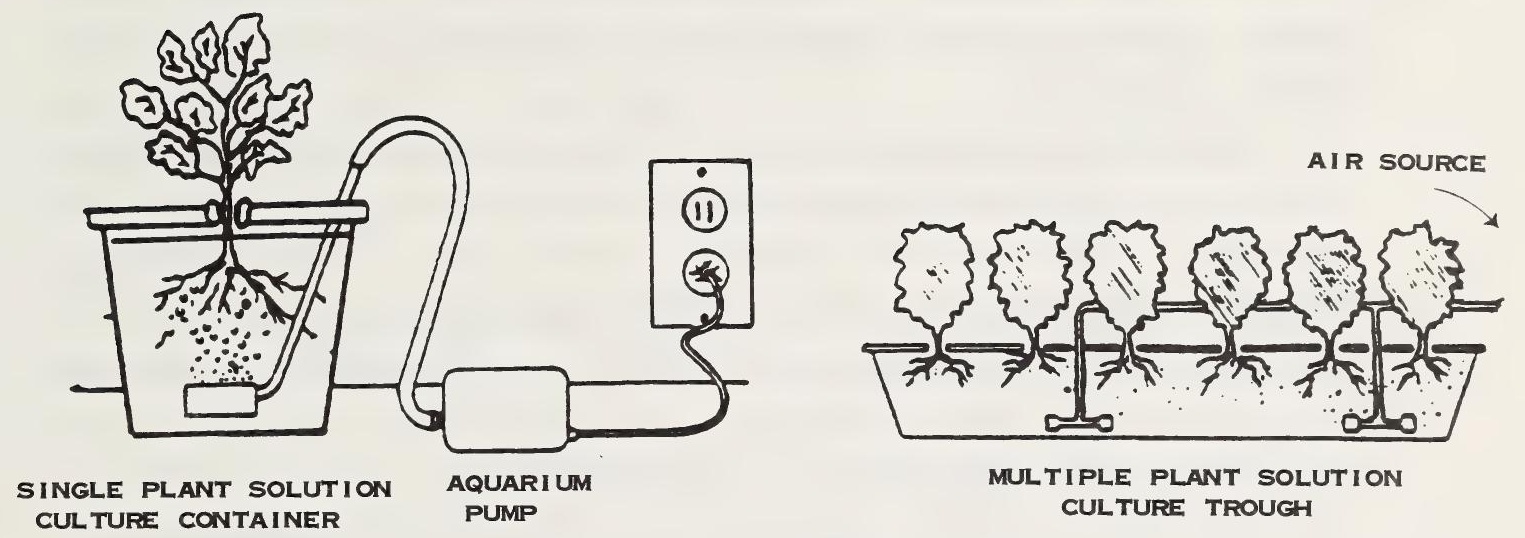

Figure 1: Typical Container for SinglePlant Solution CultureAquarium Pump Supplies Operation.

Figure 2: Aeration for Multiple-plant Solution Culture Trough Provided by an Outside Source.
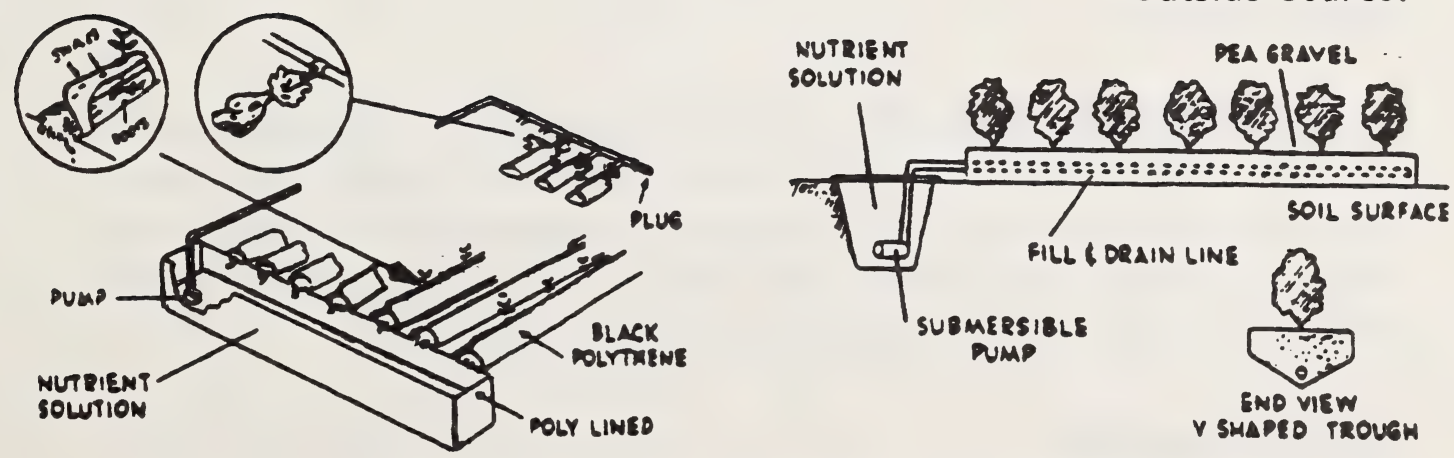

Fig. 3: Nutrient Film or Flow Culture Using Plastic Film to Hold and Feed Plants Through a Recirculation System. 
construction and management of the various alternatives are presented in several hydroponic publications.

Pea gravel and sand have been the most popular rooting media among the modified hydroponic systems, probably because both materials are universally available. Management and equipment requirements differ between gravel and sand because of their different water and nutrient holding capacities.

According to another survey of the greenhouse industry in Alberta in the fall of 1986, there were eleven hydroponic greenhouses producing cucumbers, tomatoes and lettuce. About six of the hydroponic operations were producing both cucumbers and tomatoes. Four operators were producing cucumbers and the other one was producing lettuce.

\section{Hydroponic Greenhouse Area by Type of Structure}

Total hydroponic greenhouse area surveyed for the 1985-86 study was 171,242 square feet $\left(15915 \mathrm{~m}^{2}\right)$. The area under production was 163,840 square feet $\left(15226 \mathrm{~m}^{2}\right)$ and the remaining area was used for storing greenhouse supplies and equipment. Double polyethylene construction was used for about 56 per cent of the area surveyed for hydroponic greenhouse production.

Heating Systems:

Different types of heating systems were used in the greenhouses. The most common heating systems were natural gas, steam, hot water, propane, coal, and wood. The hydroponic greenhouses surveyed used forced air natural gas furnaces for heating the facilities. Hot air was delivered by overhead polyethylene perforated tubes.

Ventilation Systems:

The polyethylene greenhouse operators have installed four foot circulation fans (number of fans depends on the size of the greenhouse), along with some jet fans for ventilation purposes. A system of trap doors along the ends of greenhouses allowed cold air in during the hot 
summer months. Some growers have installed exhaust fans and manually operated vents for proper ventilation.

Watering Systems:

Hydroponic greenhouses producing tomatoes use the basic nutrient film technique (NFT). The nutrient solution is contained in a large catchment tank, from which it is pumped through a manifold header line situated at the top of rows of canals, which are 15 to $20 \mathrm{~cm}$ wide at the base (Figure 1).

The liquid is allowed to flow into the canals at the rate of approximately two litres per minute. Leftover solution is recirculated and dumped back into storage tanks. The NFT water system has outflow and inflow pumps.

Hydroponic greenhouses producing long English cucumbers use rockwool as the growing medium. The transplants are placed directly on rockwool batts and the roots penetrate the batt. A trickle system of irrigation and fertilization is used. This system is preferred over NFT in those locations where the salt concentration of the normal water is too high. 


\section{HYDROPONIC GREENHOUSE PRODUCTION COSTS AND RETURNS}

\section{Computation of Individual Cost Components}

Interest on Investment:

Interest is defined as a sum paid or calculated for the use of capital. It is usually expressed in terms of a rate or percentage of the capital involved.

For the purposes of this study, a flat interest rate of ten per cent was used to determine a fair return to land, buildings and equipment. Interest charged against operating capital was the actual interest paid by the study participants.

Depreciation:

A ten per cent allowance was made for salvage value from the purchase price of the buildings and equipment. The following formula was used in arriving at depreciation for buildings and equipment.

$$
\text { Depreciation }=\frac{\text { Purchase Price }- \text { Salvage Value }}{\text { Number of Years of Life }}
$$

Land Value:

Land associated with the hydroponic greenhouse operation was valued at $\$ 1700$ per acre irrespective of its location. This value was determined through real estate values for good farmland suitable for a greenhouse operation. 
Property and Business Taxes:

Exact amounts of property and business taxes paid by the hydroponic greenhouse operators were included in the costs.

\section{Labour Costs:}

Hired labour costs included the amount of wages paid and any benefits received by hired workers, such as contributions to Workers' Compensation, Canada Pension Plan and Unemployment Insurance.

The hours spent by the operator and his/her family in greenhouse production were estimated. An operator's labour was valued at $\$ 7.50$ per hour and family labour was valued at a rate equal to that paid to hired labour.

Production Materials and Supplies:

Production materials and supplies included the purchase of seed, plants, growing medium (rockwool for cucumber production), fertilizers, chemicals and plastic, etc. Costs of materials and supplies were the actual figures provided by the study participants.

Greenhouse Fuel (Heating Costs):

All of the study participants had reasonably accurate costs for heating the greenhouses with natural gas. Monthly bills were very helpful in arriving at the total heating costs.

\section{Utility Costs:}

Utility costs included electricity, telephone, telegrams and water. In a situation where the utility bill included the greenhouse operator's residence, the operator was asked to apportion the bill to determine the cost for the greenhouse operation. 
Transportation Expenses (Freight, Leasing and Express):

Expenses for trucks or other vehicles owned by hydroponic greenhouse operators were apportioned according to their use in the greenhouse operation and personal and leisure driving. Freight charges paid to commercial or private carriers for hauling greenhouse produce or supplies and any other vehicle leasing/and express delivery expenses were included in the transportation costs.

Maintenance Costs:

Maintenance costs included repairs to greenhouse structures, boilers, heating equipment, watering, lighting and ventilation systems, and all other machinery and equipment associated with the greenhouse operation.

Marketing Charges:

Marketing charges were the actual amounts paid by each greenhouse operator for having produce marketed through the Co-ops at Lethbridge and Redcliff. Charges were paid for grading, packaging, marketing, and administration fees. The charges paid by each grower were included as a cost item in the study.

Miscellaneous Costs:

These costs included expenses incurred for small tools, shop supplies, bad debts, promotional expenses other than advertising, and any other expense item not covered under the above costs.

\section{Hydroponic Greenhouse Investment Costs}

Investment costs for the 1985-86 crop year were obtained directly from the study participants during the survey. Each participant was asked to value the greenhouse structure based on the current market 
value or on replacement value. Participants were also asked to provide an estimate of the life of the structure in order to calculate interest and depreciation costs.

The average land area associated with the greenhouse, such as buildings (production area and office), was 1.63 acres. Average land investment per hydroponic greenhouse amounted to \$2,775. Land investment cost (land interest) per greenhouse averaged $1 \$$ per square foot $\left(10.76 \$\right.$ per $\left.\mathrm{m}^{2}\right)$. Details on investment and investment costs are presented in Table 1.

Building Investment:

The average building investment based on the replacement value of the hydroponic greenhouse facilities amounted to \$104,769 per greenhouse. Average investment cost (interest and depreciation) on buildings was $\$ 12,994$ per greenhouse or $53 \$$ per square foot $(\$ 5.70$ per $\left.\mathrm{m}^{2}\right)$.

Equipment Investment:

The average machinery investment for the study sample, based on the purchase price of the equipment was $\$ 36,416$ per greenhouse for the study sample. The average investment cost for machinery and equipment was $20 \$$ per square foot $\left(\$ 2.15\right.$ per $\left.\mathrm{m}^{2}\right)$.

Automotive Investment:

The average investment in automobiles used for the hydroponic greenhouse operation was \$6,032 per greenhouse for the study sample. The average investment cost for automotives amounted to $3 \$$ per square foot (32屯 per $\mathrm{m}^{2}$ ). 
AVERAGE HYDROPONIC GREENHOUSE INVESTMENT AND INVESTMENT COSTS IN ALBERTA

Land Area (Acres)

Building Area (Sq. Ft.)

-dollars-

Land Value

$2,775.25$

Land Interest

277.52

Land Interest Per Sq. Ft.

0.01

Building Investment

$104,769.00$

Building Interest

$10,476.90$

Building Depreciation

$2,516.46$

Total Building Costs Per Sq. Ft.

0.53

Equipment Investment

$36,416.00$

Equipment Interest

$3,641.60$

Equipment Depreciation

$1,298.36$

Total Equipment Costs Per Sq. Ft.

0.20

Automotive Investment

$6,031.75$

Automotive Interest

603.17

Automotive Depreciation

200.33

Total Automotive Costs Per Sq. Ft.

0.03

Total Investment

$149,992.00$

Total Investment Per Sq. Ft.

6.13

Total Investment Costs

$19,014.34$

Total Investment Costs Per Sq. Ft.

0.78 
AVERAGE HYDROPONIC GREENHOUSE OPERATING COSTS

GREENHOUSE AREA (Sq. Ft.)

GROSS REVENUE

OPERATING COSTS

Growing Media and Seed

Fertilizer and Chemicals

Containers, Labels and Tags

Hired labour

Greenhouse Fuel

Utilities $^{3}$

Insurance and Registration Fees ${ }^{4}$

Repairs and Maintenance 5

Freight Leasing and Express

Property Taxes

Business Taxes

Office Supplies

Advertising

Accounting and Legal

Marketing Costs ${ }^{6}$

Travel, Donations, Memberships

Miscellaneous ${ }^{7}$

Interest on Operating Capital

AVERAGE OPERATING COST

PER GREENHOUSE

$$
\begin{gathered}
\frac{\text { TOTAL }}{24,456} \text { PER SQ. FT } \\
\begin{array}{c}
\text { - dollars - } \\
89,464 \quad 3.66
\end{array}
\end{gathered}
$$

$5,740.00 \quad 0.23$

$5,334.00 \quad 0.22$

$103.25 \quad 0.00$

$13,563.50 \quad 0.55$

$16,930.25 \quad 0.69$

$5,262.75 \quad 0.22$

$771.50 \quad 0.03$

$4,721.00 \quad 0.19$

$146.96 \quad 0.01$

$1001.50 \quad 0.04$

$56.50 \quad 0.00$

$393.50 \quad 0.02$

$70.50 \quad 0.00$

$534.50 \quad 0.02$

$9,657.25 \quad 0.40$

$165.00 \quad 0.01$

$606.50 \quad 0.02$

$2,811.00 \quad 0.12$

$67,869.44 \quad 2.78$

3 Includes power, water, telegram and telephone.

4 Includes motor vehicles, greenhouse and labor insurance.

5 Includes repairs, maintenance and fuel expenses for equipment, buildings and motor vehicles.

6 Includes commission and other marketing costs.

7 Includes small tools, shop supplies, soil testing, and promotional expenses other than advertising. 
Total Investment and Investment Costs:

For the four study participants, the average investment per hydroponic greenhouse was $\$ 149,992$. The average investment per square foot of greenhouse area was $\$ 6.13\left(\$ 65.96\right.$ per $\left.\mathrm{m}^{2}\right)$. The average investment cost per square foot amounted to $78 \$\left(\$ 8.39\right.$ per $\left.\mathrm{m}^{2}\right)$.

\section{Hydroponic Greenhouse Operating Costs}

Hydroponic greenhouse operating costs include all costs incurred during the production of crops. Some of the most common operating costs are hired labour, material inputs (seed, chemicals, fertilizers and growing medium), greenhouse fuel (heating costs), repairs and maintenance, power, water, marketing costs, property taxes and other greenhouse supplies. The average operating costs incurred in hydroponic greenhouses are presented in Table 2. The highest operating cost item was greenhouse fuel at $\$ 16,930$ followed by hired labour at $\$ 13,563$ and marketing costs at $\$ 9,657$ The average growing media and seed cost was estimated at $\$ 5,740$ per greenhouse (23\$ per square foot). Details on other operating costs are presented in Table 2.

\section{Hydroponic Greenhouse Production Costs and Returns}

The results presented in Tables 2 and 3 show that the major costs in hydroponic greenhouse operations were labour (hired, operator and family), followed by greenhouse fuel and utilities, material inputs (growing media, seed, chemicals, fertilizers, containers and labels), marketing costs, repairs and maintenance. Production costs related to the above were 31 per cent, 21 per cent, 11 per cent, 9 per cent and 4 per cent, respectively.

The average production cost for the hydroponic greenhouses surveyed for the 1985-86 crop year amounted to $\$ 105,579$, or $\$ 4.32$ per square foot: $\left(\$ 46.48\right.$ per $\left.\mathrm{m}^{2}\right)$. The average gross revenue per hydroponic greenhouse producing cucumbers and tomatoes was $\$ 89,464$, or $\$ 3.66$ per square foot $\left(\$ 39.38\right.$ per $\left.\mathrm{m}^{2}\right)$. 
Average return over operating costs was positive, at $\$ 21,595$ per greenhouse or $88 ₫$ per square foot $\left(\$ 9.47\right.$ per $\left.\mathrm{m}^{2}\right)$. However, the average return to management was negative by about $\$ 16,115$ per hydroponic greenhouse, or $66 \$$ per square foot $\left(\$ 7.10\right.$ per $\left.\mathrm{m}^{2}\right)$. Details on operating costs, other costs and management factors are presented in Table 3 .

\section{Investment Costs for Hydroponic Greenhouses Producing Cucumbers}

The study participants were divided into two groups according to the type of crops produced. They were asked to provide estimates of costs for each crop produced in the greenhouse. The four study participants all produced both cucumbers and tomatoes. Land area associated with the hydroponic greenhouse, along with buildings, equipment, and automotives used for each crop, was apportioned to arrive at an average investment and investment costs.

The average land area associated with the cucumber production area of the greenhouse was 1.5 acres. The average land interest cost amounted to $1 \$$ per square foot $\left(10.76 \$\right.$ per $\left.\mathrm{m}^{2}\right)$. The average greenhouse area for cucumber production was 21,797 square feet.

The average land, buildings, equipment and automotive investment was $\$ 133,929$ per greenhouse or $\$ 6.14$ per square foot $\left(\$ 66.07\right.$ per $\left.\mathrm{m}^{2}\right)$. The average investment cost for hydroponically produced cucumbers was $\$ 16,349$ per greenhouse (including interest and depreciation), or $75 \$$ per square foot $\left(\$ 8.07\right.$ per $\left.\mathrm{m}^{2}\right)$. Details on average investment and investment costs for cucumber production are presented in Table 4 .

\section{Operating Costs for Hydroponic Greenhouses Producing Cucumbers}

The average operating costs for hydroponic greenhouses producing cucumbers amounted to $\$ 58,791$, or $\$ 2.70$ per square foot $(\$ 29.05$ per $\mathrm{m}^{2}$ ). The largest cost item was greenhouse fuel, at $\$ 14,266$ per greenhouse, followed by hired labour and marketing costs, at \$14,150 and $\$ 7,904$, respectively. The average cost for growing media and seed was $\$ 6,317$ per greenhouse. Details on individual operating cost items are given in Table 5 . 
AVERAGE HYDROPONIC GREENHOUSE PRODUCTION COSTS AND RETURNS IN ALBERTA

A. AVERAGE AREA (Sq. Ft.) $\frac{\text { TOTAL }}{24,456}$ PER SQ. FT. - dollars -

RETURNS - GROSS REVENUE 89,464 3.66

B. OPERATING COSTS

Material Inputs

Containers, Labels and Tags

Hired labour

Greenhouse Fuel

Utilities

Insurance and Registration Fees

Repairs and Maintenance

Taxes

Freight, Leasing and Express

Advertising

Accounting and Legal

Marketing Costs

Miscellaneous ${ }^{8}$

Interest on Operating Capital

TOTAL OPERATING COSTS

C. OTHER COSTS

Land, Bldg., Equip. Interest

Depreciation

Operator's labour

TOTAL OTHER COSTS

TOTAL PRODUCTION COSTS

D. MANAGEMENT FACTORS

RETURN OVER OPERATING COSTS

RETURN TO MANAGEMENT

$\begin{array}{rr}11,074.00 & 0.45 \\ 103.25 & 0.00 \\ 13,563.50 & 0.55 \\ 16,930.25 & 0.69 \\ 5,262.75 & 0.22 \\ 771.50 & 0.03 \\ 4,721.00 & 0.19 \\ 1,058.00 & 0.04 \\ 146.96 & 0.01 \\ 70.50 & 0.00 \\ 534.50 & 0.02 \\ 9,657.25 & 0.40 \\ 1,165.00 & 0.05 \\ 2,811.00 & 0.12 \\ 67,869.44 & 2.78\end{array}$

$14,999.20$

0.61

$4,014.81$

0.17

$18,696.00$

0.76

$37,710.00$

1.54

$105,579.37$

4.32

$21,594.56$

0.88

$(16,115.37)$

$(0.66)$

8 Includes tools, shop supplies, office supplies, donations, memberships, travel, and promotional expenses other than advertising. 


\section{Producing Cucumbers}

The average gross revenue for hydroponic greenhouses producing cucumbers was $\$ 77,581$ in 1985-86. Gross revenue per square foot of the greenhouse production area was $\$ 3.56\left(\$ 38.31\right.$ per $\left.\mathrm{m}^{2}\right)$.

The average total production cost for hydroponic greenhouses producing cucumbers was $\$ 87,930$ per greenhouse, or $\$ 4.03$ per square foot $\left(\$ 43.36\right.$ per $\left.\mathrm{m}^{2}\right)$. When total production costs were deducted from the gross revenue, return to management was negative by $47 \$$ per square foot $\left(\$ 5.06\right.$ per $\left.\mathrm{m}^{2}\right)$. However, when operating costs were deducted from the average gross revenue, average return to operating costs was positive by $86 \$$ per square foot $\left(\$ 9.25\right.$ per $\left.\mathrm{m}^{2}\right)$.

The major operating costs for hydroponic greenhouses producing cucumbers were greenhouse fuel, hired labour, material inputs and marketing costs. A breakdown of all operating and investment costs for hydroponic greenhouse cucumber production is presented in Table 6 .

\section{Investment Costs for Hydroponic Greenhouses Producing Tomatoes}

As mentioned above, the hydroponic production area reported by the study participants was divided by type of crops produced. The average land area associated with a greenhouse producing tomatoes was 0.90 acre. Land was valued at $\$ 1,700$ per acre.

Investment for buildings, equipment and automotive is given in Table 7. The average total investment for land, buildings, equipment and automotive amounted to $\$ 66,481$ or $\$ 6.15$ per square foot $(\$ 66.17$ per $\left.\mathrm{m}^{2}\right)$. The average investment cost was about $83 \$$ per square foot $(\$ 8.93$ per $\mathrm{m}^{2}$ ) in the 1985-86 crop year for hydroponic tomatoes.

\section{Operating Costs for Hydroponic Greenhouses Producing Tomatoes}

Details on the average operating cost for hydroponic greenhouses producing tomatoes are presented in Table 8. Greenhouse fuel (heating cost) was the highest cost item, at $\$ 8,307$ per greenhouse, or $77 \$$ per 
AVERAGE HYDROPONIC GREENHOUSE INVESTMENT AND INVESTMENT COSTS FOR CUCUMBERS

Land Area (Acres)

Building Area (Sq. Ft.)

-dollars-

Land Value

$2,567.00$

Land Interest

256.00

Land Interest Per Sq. Ft.

0.01

Building Investment

$94,446.62$

Building Interest

$9,444.66$

Building Depreciation

$1,772.39$

Total Building Costs Per Sq. Ft.

0.51

Equipment Investment

$31,989.33$

Equipment Interest

$3,198.93$

Equipment Depreciation

$1,024.74$

Total Equipment Costs Per Sq. Ft.

0.19

Automotive Investment

$4,925.66$

Automotive Interest

492.57

Automotive Depreciation

158.83

Total Automotive Costs Per Sq. Ft.

0.03

Total Investment

$133,928.62$

Total Investment Per Sq. Ft.

6.14

Total Investment Costs ${ }^{9}$

$16,348.81$

Total Investment Costs Per Sq. Ft.

0.75

9 Includes interest and depreciation. 
AVERAGE HYDROPONIC GREENHOUSE OPERATING COSTS FOR CUCUMBERS

GREENHOUSE AREA (Sq. Ft.)

GROSS REVENUE

OPERATING COSTS

Growing Media and Seed

Fertilizer and Chemicals

Containers, Labels and Tags

Hired labour

Greenhouse Fuel

Utilities $^{10}$

Insurance and Registration Fees ${ }^{11}$

Repairs and Maintenance ${ }^{12}$

Freight Leasing and Express

Property Taxes

Business Taxes

Office Supplies

Advertising

Accounting and Legal

Marketing Costs ${ }^{13}$

Travel, Donations, Memberships

Miscellaneous ${ }^{14}$

Interest and Operating Capital

AVERAGE OPERATING COSTS

PER GREENHOUSE

\begin{tabular}{|c|c|}
\hline TOTAL & PER SQ. FT. \\
\hline \multicolumn{2}{|l|}{21,797} \\
\hline \multicolumn{2}{|c|}{ - dollars - } \\
\hline $77,580.62$ & 3.56 \\
\hline
\end{tabular}

$6,316.66 \quad 0.29$

$3,988.67 \quad 0.18$

$137.67 \quad 0.01$

$14,150.00 \quad 0.65$

$14,266.33 \quad 0.65$

$3,608.00 \quad 0.17$

$810.67 \quad 0.04$

$3,752.67 \quad 0.17$

$118.67 \quad 0.01$

$1,332.00 \quad 0.06$

$5.33 \quad 0.00$

$524.67 \quad 0.02$

$22.00 \quad 0.00$

$506.67 \quad 0.02$

$7,904.00 \quad 0.36$

$186.67 \quad 0.01$

$505.00 \quad 0.02$

$647.33 \quad 0.03$

$58,783.00 \quad 2.70$

10 Includes power, water, telegram and telephone.

11 Includes motor vehicles, greenhouse and labor insurance.

12 Includes repair, maintenance and fuel expenses for equipment, buildings and motor vehicles.

13 Includes commission and other marketing costs.

14 Includes small tools, shop supplies and promotional expenses other than advertising. 
square foot $\left(\$ 8.29\right.$ per $\left.\mathrm{m}^{2}\right)$. It was followed by marketing costs, hired labour, and fertilizers and chemicals, at \$4,939, \$3,934 and \$3,123 respectively. The average total operating cost amounted to $\$ 31,542$, or $\$ 2.92$ per square foot $\left(\$ 31.42\right.$ per $\left.\mathrm{m}^{2}\right)$.

Production Costs and Returns for Hydroponic Greenhouses

\section{Producing Tomatoes}

The average gross revenue for hydroponic greenhouse operators producing tomatoes was $\$ 41,704$ per greenhouse, or $\$ 3.86$ per square foot $\left(\$ 41.53\right.$ per $\mathrm{m}^{2}$ ), in 1985-86. Gross revenue per square foot of tomatoes was marginally higher when compared to gross revenue for cucumbers.

The average return over operating costs for tomatoes was $\$ 0.94$ per square foot $\left(\$ 10.12\right.$ per $\left.\mathrm{m}^{2}\right)$, compared to $86 \$$ per square foot $(\$ 9.25$ per $\mathrm{m}^{2}$ ) for cucumbers. The average return to management was also negative for tomatoes by $\$ 1.01$ per square foot $\left(\$ 10.87\right.$ per $\left.\mathrm{m}^{2}\right)$.

As indicated above, the highest operating cost item was greenhouse fuel at $77 \$$ per square foot $\left(\$ 8.29\right.$ per $\left.\mathrm{m}^{2}\right)$, followed by marketing costs at $46 \$$ per square foot $\left(\$ 4.95\right.$ per $\left.\mathrm{m}^{2}\right)$, material inputs at $41 \$$ per square foot $\left(\$ 4.41\right.$ per $\left.\mathrm{m}^{2}\right)$ and hired labour at $36 \$$ per square foot $(\$ 3.87$ per $\mathrm{m}^{2}$ ). Details on various operating cost items, investment and investment costs and mangement factors are presented in Table 9. 
A. AVERAGE AREA (Sq. Ft.)

RETURNS - GROSS REVENUE

B. OPERATING COSTS

Material Inputs

Containers, Labels and Tags

Hired labour

Greenhouse Fuel

Utilities

Insurance and Registration Fees

Repairs and Maintenance

Taxes

Freight, Leasing and Express

Advertising

Accounting and Legal

Marketing Costs

Miscellaneous 15

Interest and Operating Capital

TOTAL OPERATING COSTS

C. OTHER COSTS

Land, Bldg., Equip. Interest

Depreciation

Operator's labour

TOTAL OTHER COSTS

TOTAL PRODUCTION COSTS

D. MANAGEMENT FACTORS

RETURN OVER OPERATING COSTS

RETURN TO MANAGEMENT
TOTAL PER SQ. FT.

21,797

- dollars -

$77,580.62$

3.56

$10,305.33$

0.47

137.67

0.01

$4,150.00$

0.65

$14,266.33$

0.65

$3,608.00$

0.17

810.67

0.04

$3,752.67$

0.17

1337.33

0.06

118.67

0.01

22.00

0.00

506.67

0.02

$7,904.00$

0.35

$1,216.34$

0.06

647.33

0.03

$58,783.00$

2.70

$13,392.86$

0.60

$2,955.65$

0.13

$12,798.00$

0.57

$29,146.51$

1.34

$87,929.51$

4.03

$18,797.62$

0.86

$(10,348.82)$

$(0.47)$

15 Includes small tools, shop supplies, office supplies, donations, memberships, travel and promotional expenses other than advertising . 
AVERAGE HYDROPONIC GREENHOUSE INVESTMENT AND INVESTMENT COSTS FOR TOMATOES

Land Area (Acres)

0.90

Building Area (Sq. Ft.)

10,812

-dollars-

Land Value

$1,530.00$

Land Interest

153.00

Land Interest Per Sq. Ft.

0.01

Building Investment

$45,245.00$

Building Interest

$4,524.53$

Building Depreciation

$1,566.69$

Total Building Costs Per Sq. Ft.

0.56

Equipment Investment

$16,588.66$

Equipment Interest

$1,658.87$

Equipment Depreciation

697.98

Total Equipment Costs Per Sq. Ft.

0.22

Automotive Investment

$3,116.67$

Automotive Interest

311.67

Automotive Depreciation

108.28

Total Automotive Costs Per Sq. Ft.

0.04

Total investment

$66,480.62$

Total Investment Per Sq. Ft.

6.15

Total Investment Costs ${ }^{16}$

$9,021.01$

Total Investment Costs Per Sq. Ft.

0.83

16 Includes interest and depreciation. 
AVERAGE HYDROPONIC GREENHOUSE OPERATING COSTS FOR TOMATOES

GREENHOUSE AREA (Sq. Ft.)

GROSS REVENUE

OPERATING COSTS

Growing Media and Seed

Fertilizer and Chemicals

Containers, Labels and Tags

Hired labour

Greenhouse Fuel

Utilities $^{17}$

Insurance and Registration Fees ${ }^{18}$

Repairs and Maintenance 19

Freight Leasing and Express

Property Taxes

Business Taxes

Office Supplies

Advertising

Accounting and Legal

Marketing Costs 20

Travel, Donations and Memberships

Miscellaneous 21

Interest and Operating Capital

AVERAGE OPERATING COSTS

PER GREENHOUSE

$$
\begin{gathered}
\frac{\text { TOTAL }}{10,812} \text { PER SQ. FT. } \\
\begin{array}{c}
\text { - dollars - } \\
41,704 \quad 3.86
\end{array}
\end{gathered}
$$

$\begin{array}{ll}1,336.67 & 0.12 \\ 3,123.33 & 0.29\end{array}$

$3,934.33$

0.36

$8,307.33$

0.77

$3,379.00$

0.31

198.00

0.02

$2,542.00$

0.24

77.33

0.01

3.25

0.00

70.00

0.01

$\begin{array}{rr}22.00 & 0.00 \\ 205.67 & 0.02 \\ 4.939 .00 & 0.46\end{array}$

303.58

0.03

$3,100.67$

0.29

$31,542.16$

2.92

17 Includes power, water, telegram and telephone.

18 Includes motor vehicles, greenhouse and labor insurance.

19 Includes repair, maintenance and fuel expenses for equipment, buildings and motor vehicles.

20 Includes commission and other marketing costs.

21 Includes small tools, shop supplies, soil testing and promotional expenses other than advertising. 


\section{A. AVERAGE AREA (Sq. Ft.)}

RETURNS - GROSS REVENUE

B. OPERATING COSTS

Material Inputs

Containers, Labels and Tags

Hired labour

Greenhouse Fuel

Utilities

Insurance and Registration Fees

Repairs and Maintenance

Taxes

Freight, Leasing and Express

Advertising

Accounting and Legal

Marketing Costs

Miscellaneous 22

Interest and Operating Capital

TOTAL OPERATING COSTS

C. OTHER COSTS

Land, Bldg., Equip. Interest

Depreciation

Operator's labour

TOTAL OTHER COSTS

TOTAL PRODUCTION COSTS

D. MANAGEMENT FACTORS

RETURN OVER OPERATING COSTS

RETURN TO MANAGEMENT

$\frac{\text { TOTAL }}{10,812}$ PER SQ. FT.
$\begin{aligned} & - \text { dollars - } \\ & 41,704.00 \quad 3.86\end{aligned}$

$$
4,460.00
$$

0.41

$\begin{array}{rr}3,934.33 & 0.36 \\ 8,307.33 & 0.77 \\ 3,379.00 & 0.31 \\ 198.00 & 0.02 \\ 2,542.00 & 0.24 \\ 73.25 & 0.01 \\ 77.33 & 0.01 \\ 22.00 & 0.00 \\ 205.67 & 0.02 \\ 4,939.00 & 0.46 \\ 303.58 & 0.03 \\ 3,100.67 & 0.29 \\ 31,542.16 & 2.92\end{array}$

$6,648.06$

0.61

$2,372.50$

0.22

$12,130.00$

1.12

$21,150.51$

1.96

$52,692.60$

4.87

$10,161.84$

0.94

$(10,988.60)$

(1.01)

22 Includes small tools, shop supplies, office supplies, donations, memberships, travel and promotional expenses, other than advertising. 
The information presented in Table 10 will be of particular significance to the study participants and any other hydroponic greenhouse operator, as it provides an opportunity to compare individual costs and returns with those of the study sample. Although the sample size for the hydroponic greenhouse production costs and returns study was relatively small, it still provided useful results for potential greenhouse operators and showed the study participants in which areas to reduce their costs.

Table 10 lists average costs and returns data for the study sample only. The average operating and investment cost items have been broken down to the possible details in order to assist the users of the report to identify various costs. Besides the detailed breakdown of the costs, a column has been left blank for the personal use of the study participants and/or the potential users of this information. Each study participant received a personalized report on his/her hydroponic greenhouse operation along with the results of the study sample. 

A. AVERAGE AREA (Sq. Ft.)

RETURNS - GROSS REVENUE

B. OPERATING COSTS

Material Inputs

Containers, Labels and Tags

Hired labour

Greenhouse Fuel

Utilities

Insurance and Registration Fees

Repairs and Maintenance

Taxes

Freight, Leasing and Express

Advertising

Accounting and Legal

Marketing Costs

Miscellaneous 23

Interest on Operating Capital

TOTAL OPERATING COSTS

C. OTHER COSTS

Land, Bldg., Equip. Interest

Depreciation

Operator's labour

TOTAL OTHER COSTS

TOTAL PRODUCTION COSTS

D. MANAGEMENT FACTORS

RETURN OVER OPERATING COSTS

RETURN TO MANAGEMENT

$\begin{gathered}\text { Study } \\ \text { Sample }\end{gathered}$
$\begin{gathered}\text { Your } \\ \text { Greenhouse }\end{gathered}$
- dollars -
$89,464.00$

$11,074.00$

103.25

$13,563.50$

$16,930.25$

$5,262.75$

771.50

$4,721.00$

$1,058.00$

146.96

70.50

534.50

$9,657.25$

$1,165.00$

$2,811.00$

$67,869.44$

$14,999.20$

4,014.81

$18,696.00$

$37,710.00$

$105,579.37$

$21,594.56$

$(16,115.37)$

23 Includes small tools, shop supplies, office supplies, donations, memberships, travel and promotional expenses, other than advertising. 


\section{SUMMARY}

This section provides summaries of the 1985-86 costs and returns for the hydroponic greenhouse operations surveyed in the winter of 1987. Five hydroponic greenhouse operators participated in the survey. As information provided by one operator was inadequate, analysis in the report is based on four hydroponic greenhouse operations. The information furnished by the one operator was for production of lettuce by hydroponics.

The average production cost and return for hydroponic greenhouses producing both cucumbers and tomatoes is presented in Table 11. The major production costs were labour (hired, operator and family), greenhouse fuel, investment costs and material inputs. The relative share of these costs of the total production costs for the study sample was 31 per cent, 16 per cent, 14.6 per cent and 11 per cent, respectively. Other significant cost items were marketing costs, repairs, maintenance and utilities costs.

The average production cost for a hydroponic greenhouse operation of 24,456 square feet amounted to $\$ 105,579$, or $\$ 4.32$ per square foot $\left(\$ 46.48\right.$ per $\left.\mathrm{m}^{2}\right)$. These costs were higher, by about $66 \$$ per square foot $\left(\$ 7.10\right.$ per $\left.\mathrm{m}^{2}\right)$, than the average gross revenue of $\$ 3.66$ per square foot $(\$ 39.38)$, resulting a negative return to management. The average operating cost for a hydroponic greenhouse operation was $\$ 67,869$ or $\$ 2.78$ per square foot $\left(\$ 29.91\right.$ per $\left.\mathrm{m}^{2}\right)$. When these costs were deducted from the gross revenue, average greenhouse operation showed a profit of $\$ 21,596$ or $88 \$$ per square foot $\left(\$ 9.47\right.$ per $\left.\mathrm{m}^{2}\right)$.

The hydroponic greenhouse study participants produced both cucumbers and tomatoes. Therefore, investment costs were proportioned according to the area of the greenhouse used for the production of each crop. The study participants were able to provide a break down of operating costs for each crop. 
Average Acre (Sq. Ft.)

Gross Revenue

Gross Revenue/Sq. Ft.

OPERATING COSTS

Material Inputs

Hired labour

Greenhouse Fuel

Market Costs

Other Operating Costs

TOTAL OPERATING COSTS PER SQ. FT.

OTHER COSTS

Land, Bldgs, and Equip.

Interest and Deprec.

Operator's labour

TOTAL PRODUCTION COSTS PER SQ. FT.
Study

Sample Cucumbers Tomatoes

$$
24,456
$$

21,797

10,812

- - dollars - -

$89,464.00$

$77,581.00$

$41,704.00$

3.66

3.56

3.86

$\begin{array}{rrr}11,177.25 & 10,443.00 & 4,460.00 \\ 13,563.50 & 14,150.00 & 3,934.33 \\ 16,930.25 & 14,266.33 & 8,307.33 \\ 9,657.25 & 7,904.00 & 4,939.00 \\ 16,360.44 & 12,019.67 & 9,901.50\end{array}$

$67,869.44$

$58,783.00$

$31,542.16$

2.78

2.70

2.92 
The average total production cost for the hydroponic area used for producing cucumbers amounted to $\$ 87,930$, or $\$ 4.03$ per square foot $\left(\$ 43.36\right.$ per $\mathrm{m}^{2}$ ). The average gross revenue for the same area amounted to $\$ 77,581$, or $\$ 3.56$ per square foot $\left(\$ 38.31\right.$ per $\left.\mathrm{m}^{2}\right)$. The average return to management was negative by $\$ 10,349$ or $47 \$$ per square foot $\left(\$ 5.06\right.$ per $\left.\mathrm{m}^{2}\right)$. Return over operating costs for the cucumber production area of the greenhouse was $\$ 18,798$, or $86 \$$ per square foot $\left(\$ 9.25 \mathrm{~m}^{2}\right)$. Details on gross revenue and various cost items are given in Table 11.

The average production cost for the hydroponic area producing tomatoes amounted to $\$ 52,693$, or $\$ 4.87$ per square foot $\left(\$ 52.40\right.$ per $\left.\mathrm{m}^{2}\right)$. The average gross revenue for the same area was $\$ 41,704$, or $\$ 3.86$ per square foot $\left(\$ 41.53\right.$ per $\left.\mathrm{m}^{2}\right)$. Return to management for tomato production was also negative by $\$ 10.909$ or $\$ 1.01$ per square $(\$ 10.87$ per $\mathrm{m}^{2}$ ). However, return over operating costs was positive by $\$ 10,166$, or $94 \$$ per square foot $\left(\$ 10.12\right.$ per $\left.\mathrm{m}^{2}\right)$.

A comparison of gross returns between cucumbers and tomatoes indicated that tomatoes were marginally more profitable than cucumbers, despite higher unit costs. A cost comparison between the two crops showed that both investment and operating costs were higher for tomatoes.

\section{Distribution of Hydroponic Greenhouse Production Costs}

The various cost items for production of cucumbers and tomatoes by hydroponics were grouped to indicate the proportion of the major cost items in percentages. Figure 4 shows the distribution of various cost components for the hydroponic greenhouses surveyed in the winter of 1987. Labour costs (hired, operator and family) accounted for about one-third of the total production costs (30.6 per cent), followed by greenhouse fuel at 16.1 per cent and investment costs (interest on land, interest and depreciation on buildings, equipment and automotives) at 18.1 per cent. Material inputs and marketing costs (growing media, seed, fertilizers, chemicals, containers, labels and tags) accounted for about 10.6 per cent and 9.2 per cent of the total production costs, respectively. 
Figure 4: Distribution of Hydroponic Greenhouse Production Costs

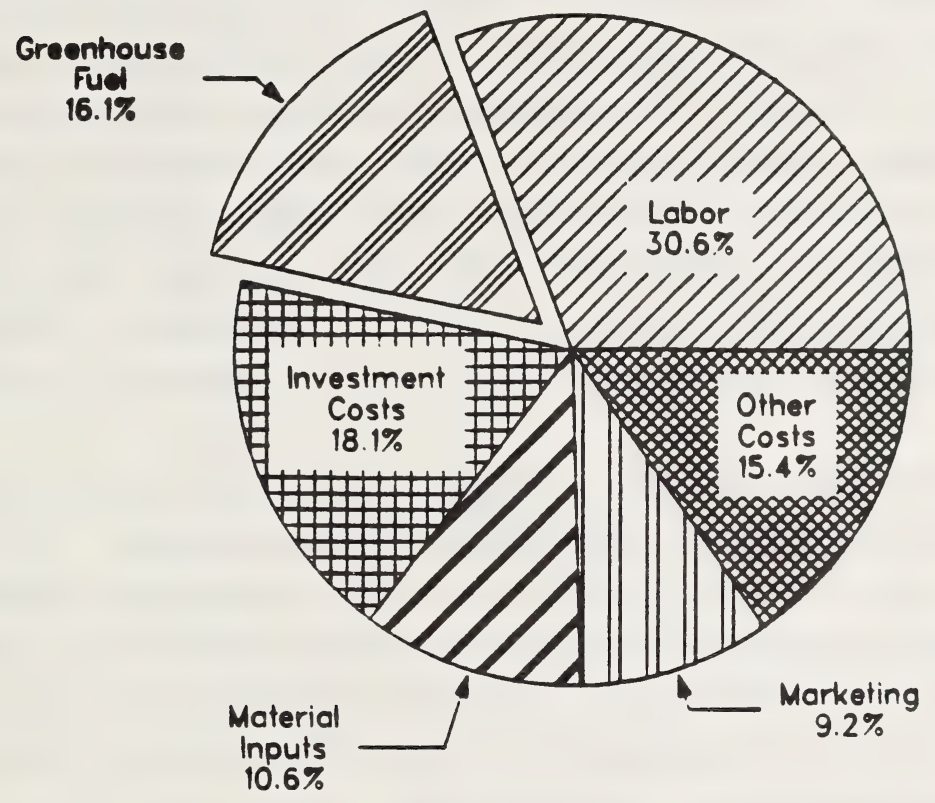

Figure 5: Distribution of Hydroponic Greenhouse Production Costs for Cucumbers

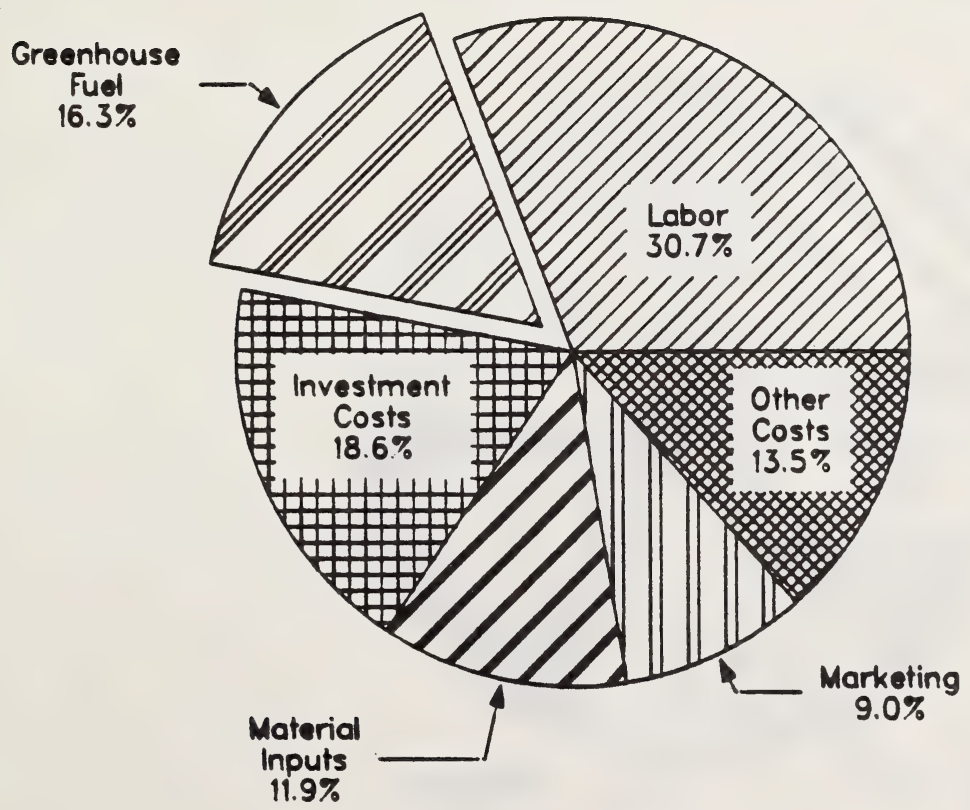


Figure 5 shows the distribution of various cost components for hydroponic production of cucumbers in Alberta. As indicated earlier, hydroponic greenhouse production areas were distributed by crops produced. For the production of cucumbers, the major cost items were labour, 30.7 per cent, greenhouse fuel, 16.3 per cent, investment costs (interest on land, interest and depreciation on buildings, equipment and automotives) 18.6 per cent, and material input costs, 11.9 per cent. The balance accounted for marketing costs, repairs and maintenance, utilities (power and water), taxes, and other greenhouse operation related supplies.

Figure 6 shows the distribution of various cost components for the areas of hydroponic greenhouses allocated to tomato production. As in other situations, labour (hired, operator and family) was the highest cost item at over 30.5 per cent, followed by greenhouse fuel at 15.8 per cent, investment costs at about 17.2 per cent, marketing costs at 9.4 per cent and material input costs at 8.5 per cent. The balance accounted for other costs.

Figure 6: Distribution of Hydroponic Greenhouse Production Costs for Tomatoes

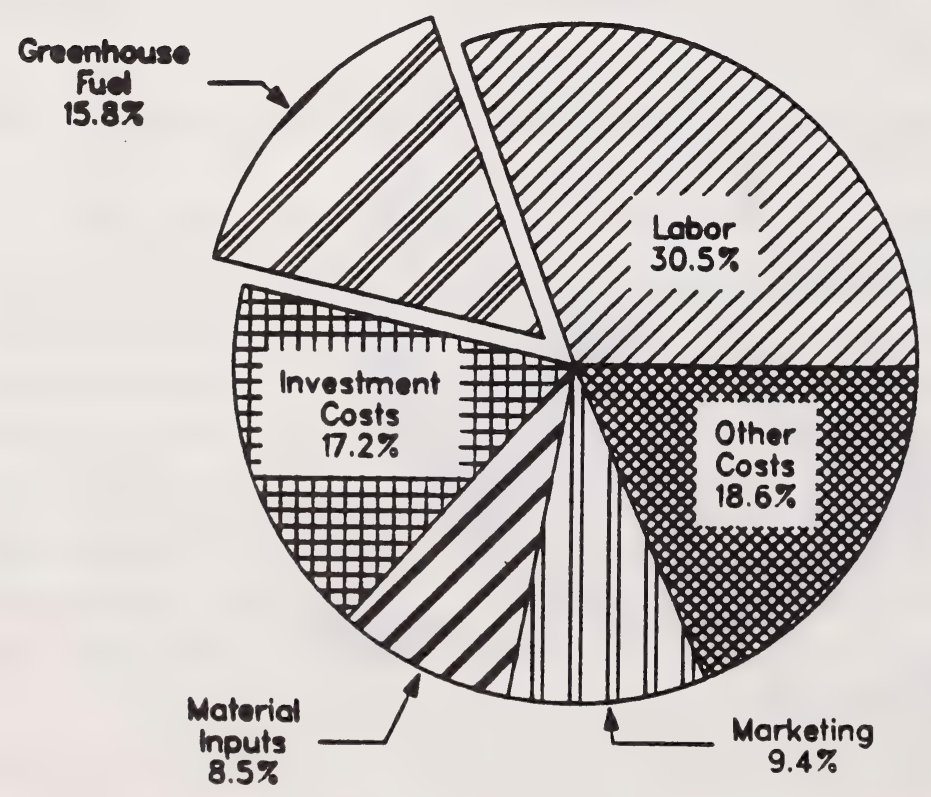


Following are some of the concerns and/or problems expressed/ indentified by the study participants:

1. Increases in natural gas cost is one of the major factors which could affect winter production of crops.

2. Fluctuations in prices of produce are too extreme, thus not allowing any long term planning. Imports from British Columbia, Ontario and the United States are responsible for price fluctuations.

3. Availability of reliable labour is a continuing problem which could hamper the expansion of the greenhouse industry in the province.

4. A few of the growers experienced some production and marketing problems. Production per plant needs to be increased in order to break even.

5. Lack of low interest funds to existing greenhouse operators, thus cannot make improvements to the facilities. 



N.L.C. - B.N.C. 